Pakistan Journal of Education

Vol.37, No.1, 2020, 113-128

\title{
Semiotic analysis of English books of Punjab Textbook Board (Pakistan) with Gender Lens: Exploring the gender sensitization level of Punjab Textbook Board officers
}

\author{
Tahira Akbar* \\ Ra'ana Malik*
}

\begin{abstract}
Semiotics is visual literacy which is an important aspect of learning process involving various social aspects of a society. Visuals are used dominantly in all books of early learners because it is considered the most efficient way of learning and teaching. Representation of gender through visual literacy is the most current and debatable social issue in the contemporary world. Though in Punjab Textbook Board, the text books of almost all subjects including English textbooks of all classes are supplemented with visuals. English is made a compulsory subject from class 1 till 10 and are always in lime light at international level. But unfortunately this aspect of gender is being neglected in the English textbooks of Punjab, Pakistan. Interviews were conducted from the officers of textbook board to explore the level of sensitization regarding gender and its representation. These interviews revealed that they are unable to understand the true concept of gender due to which male and female are still presented in stereotypical ways. Through interviews it was seen that this inability of true understanding and representation of gender is due to the officials' unawareness, cost constraints of management and social norms.
\end{abstract}

Keywords: visual literacy, gender, textbooks, Punjab

\footnotetext{
* Ph.D Scholar, Department of Gender Studies, University of the Punjab, Lahore * Professor \& Chairperson, Department of Gender Studies, University of the Punjab, Lahore
} 


\section{Introduction}

Visual literacy is becoming essential in modern days' life (Elkins, 2010) which starts from a person's first attempt of learning by entering in school. Visuals are used dominantly in all books of early learners because it is considered the most efficient way of learning (Elkins, 2010). By defining visual literacy, it is said having ability to understand the overt and covert message conveyed through the visual (Briggs, 2015) and syllabus textbooks including English textbooks are mostly supplemented by visuals to make the learning process more efficient. In Punjab, Textbooks of almost all subjects including English Textbooks of all classes are supplemented with visuals in the books. Hence, under this article it is studied that how gender is represented in English textbooks of Punjab Textbook Board from the perspective of those who are responsible for designing and compilation of books of Punjab Textbook Board. As the researches have proved that visuals illustrating biasness for any particular gender in textbooks affect the learners' way of thinking for that gender (Yazdanmehr \& Shoghi, 2014).

English is the second language in Pakistan but all official communication is done in English at national and international level. Therefore, English is considered compulsory along with Urdu, Math, Science and Islamic Studies from class one till graduation in all four provinces of Pakistan. In most of the schools, especially in private schools, English remains the medium of instruction and interaction among students and teachers not only at all senior levels but at junior level also. English is also considered a status symbol that's why students are encouraged to learn English from the beginning for higher studies and better social status (UNESCO, 2004). The private schools advertise English as their medium of instruction to attract parents as a reason to opt for private schooling of their children. Though Urdu is lingua franca and national language but in Punjab the role of English is strengthened even in state schools.

Punjab is the second largest province of Pakistan by area after Baluchistan hosting half of the country's population which is 80 million according to the National censes (2017).Punjab Textbook Board publishes textbooks for the entire province having a diversified sociocultural dynamics using visuals which promote national policies too. Achieving gender equality by eradicating various forms of gender oppression from the society remained a prime objective of Pakistan Government and for that all the means are utilized including the textbooks. Assuming the images presented in the textbooks express a strong message which might affect the learners' psyche therefore, it 
becomes important to analyze that either the presented images conveyed a gender biased or neutral message (Yazdanmehr \& Shoghi, 2014). They have argued that education is for the holistic development of the students as they get inspired by the gendered role models displayed in their textbooks appropriately reflecting the sense prevailing in a society. They further argued that textbook images also develop students' self-esteem by reflecting an appropriate gender role.

The main aim of the Punjab Textbook Board is to publish English textbooks to make students able to comprehend English and communicate in this language fluently. Along with this aim of teaching them English language, many messages are also conveyed through verbal and nonverbal language. Punjab Textbook Board is now practicing an open bidding process for publishing textbooks through which any commercial publisher can develop manuscript and deliver publishing facilities with his personal team of authors. Various manuscripts of different authors are submitted which further go through the process of evaluation. Then a committee does a discussion on the manuscript and finalizes a book, unanimously. This whole process is devoid of such mechanism which could stamp that the evaluation of the manuscripts happened on the basis of proper gender representation. The points under discussion with priority for the government appears such which include to decrease the cost of textbooks through keeping fewer subjects, publicizing book sharing, reducing the use of prime and major colors, to shrink presentations of pages and try to control over involvement cost from the publisher's side (Qazi, Rawat, Hamid \&Simon,2010).These factors indicate that government is concerned more to t minimize cost on textbooks rather than on an appropriate and balanced gender representation in the textbooks.

It is historically testified that textbooks are considered very important for both the teachers and the students in the process of formal education. Textbooks are considered very complex as they symbolically represent communal, ethnic, commercial and political conditions with context of a society in which these are read and understood (Chiponda \&Wassermann, 2015).It means textbooks will directly affect the student's way of thinking about the society represented in the textbooks and the society around them. As researchers have argued that textbooks provide a framework and a prearranged objective base directive (Gulzar, 2017) to the students, it becomes even crucial to present such contexts and settings where no discrimination or oppression should be traced against any particular gender.

Assuming the post-structuralism stance under which gender is considered constantly in flux due to change in time and space in a 
particular society, gender has gained attention of the researchers (Paechter, 2001). This shows that gender is produced and continually being reshaped in a society which required special attention for proper representation of gender in textbooks. The developed content in the textbooks with patriarchal mindset will eventually transfer the similar patriarchal norms in the students' minds which will further perpetuate patriarchal oppression in the society (Mirza, 2004). These books become the effective societal agent either to continue the stereotypical ideology or instruct some novel and transformed ideology. Sometimes, even the gender identities become hurdle among the proper interaction of students, textbooks, teachers and peers (Rind,2015). All chairmen and writers had firm belief in considering textbooks as a tool of change in society. Textbooks are facilitator, motivator and heart of all instructional and academic activities (Mirza, 2004). From this wider scope of curriculum, syllabus is planned to support teachers to perform their academic activities and achieve the supposed tasks. Its contents are finalized by the Education board and then the schools, institution and teachers are made bound to follow them (Gopang, Shaikh, Parveen \& Khan, 2012).

The effect of education on social issues is multidimensional, with education being both a clash driver and a platform to lessen it (Halai \& Durrani, 2018). The idea that a male can perform what a female cannot, can be grounded on their biological situations, but not on their rational, mystical or intellectual base(Akbar, Malik \& Azam,2018) as Beauvoir (1952) also argues that, "one is not born a woman, but becomes one". School textbooks have been recognized as a major shareholder for the construction of gender identities, to strengthen gender discernment and to build the prime social structures of a culture and society (Skelton \& Ullah, 2013). People are practicing gender as an ideology which is presented through signs to work as code (Hus \& Sovic, 2015). These signs can be hidden in images, pictures and visuals which are included in the textbooks. Student becomes connected with external world through variety of presented roles, activities and settings in the visuals of Textbooks.

An individual's identity is constructed through various meanings of gender in all spheres of social life which includes family, public and private sphere. Fairclough and Woodak (1997) declared school and the textbooks which are taught there, a source which represent gender in all its positive and negative aspects. These textbooks become the main source of social power and prevailing gender conventions (Kobia, 2009). Halliday (1977) presented visuals in textbooks as a very strong semiotic way through which the constituted meaning of a social structure is 
swapped. Through these textbooks, images can be shown to portray some specific group in power or as a subordinate strata of society (Kress \& Vanleewan, 2006). These images are basically signs which are composed of signifiers and signified. Through these signifiers, which contain denotative and connotative interpretations, the hidden meanings are revealed. Visuals have effective role to play as a proficient tool for instructional purpose to initiate creativity and motivation of the students (Kasmaienezhadfard, Pourrajab \& Rabbani, 2015).Messages are delivered through text and tried to make understandable with images due to which the visuals are considered an indispensable part of the textbooks. Therefore; this study aims to find out through semiotics that whether the English textbooks of Pakistan are written and published under the guidance of gender sensitive officers or not.

\section{Literature Review}

In textbooks certain ideology is used to display power relations through the usage of presented images (Woodak, 2002). Thus knowledge inculcated through these visuals of textbooks is replete with the issues of power, culture and gender roles which ultimately generate some gender ideology which is presented through signs and visuals to the people to practice. Through the visuals illustrated in the textbooks students get connected with expanded world via variety of presented roles and settings (Hus \& Sovic, 2015). Usually gender is taken as sex based without realizing that it is based on intellect (Akbar, Malik \& Azam, 2018). Presented visuals are processed by the students to articulate social and cultural meanings beside text. This importance has made images, more than the mere decorative purposes, an integral part for educational purposes.

Khurshid, Gillani and Hashmi (2010) found during a study of English and Urdu textbooks at secondary level that males were shown in very prestigious and productive activities as compared to women. Truce, Blane and Cambre (2018) commented that this is not a division or separation of information between cognition and visuals which relates to esthetic sense through all spaces and areas of constructed visibility. Multiple and sometimes contrary interpretations are invited through these visuals. Visuals are being involved in the production of indications and evidences due to its ubiquity. Visuals are a source of interpretation and explanation of visibility as an important element of social structure. Images are not only the study of a document but also a product of certain culture (Truce, Blane \&Cambre,2018). That is the reason researches find 
gender representation through visuals believing it portray and produce some certain culture, values, norms and traditions.

UNESCO (2016) has declared gender equality as a key to lubricate social cohesion by considering roles and relations of woman and man along with the way they get access to power and resources. The uneven access of women to resources and power was observed and mentioned in Pakistan Vision 2025 with an aim to redress it. Though the government of Pakistan and especially the Punjab Textbook board has been expressing their deep and sincere concern for gender equality in all spheres of life and especially in the sector of education yet it needs specialized experts to meet this challenge. With this belief that it is better to nip the evil in the bud, special attention is being paid to the primary and secondary system of school education under this research. Assuming the importance and implication of curriculum and textbooks in shaping learners' identities and values, Pakistan's 2001-2015Education for all (EFA) action plan focused on enhancing gender parity and impartiality through the elimination of gender bias in the curriculum and textbooks (Mirza, 2004). However, after more than a decade since then, the GMR, 2015 noted that gender bias in Text books 'remains pervasive' in Pakistan (UNESCO, 2015). Constant efforts are being done to eradicate this biasness.

\section{Research Purpose}

The purpose of this research is to find out that either the concept of gender represented in visuals of English textbooks of Punjab Textbook Board, is only restricted to biological categorization of male and female or more than this and covering the performativity of both sexes.

\section{Research Objectives}

The overall research objective is to analyze the visuals presented in English Textbooks of Punjab Board with gender lens. To meet this overall research objective, the researcher intends to cover a specific objective in this article by exploring the point of view of the responsible officers in publishing the textbooks of Punjab about appropriate representation of gender in the visuals used in the textbooks. The specific research objectives further include to;

1. find out gender awareness among the policy makers and writers of English textbooks of Punjab Textbook Board, Pakistan.

2. probe the concepts of visual literacy among the policy makers and writers of English textbooks of Punjab Textbook Board, Pakistan. 
3. find out the type of hurdles faced by the writers, publishers or policy makers during the process of preparing Textbooks.

\section{Methodology}

The researcher used simple qualitative research method by interviewing, in detail, the key stakeholders who were responsible for writing, approving and publishing of English textbooks. Top five officials were interviewed which included director manuscript, two writers and two publishers of English textbooks of Punjab Textbook Board. Detailed interviews were conducted from these five persons and the researcher analyzed the collected data by generating themes under thematic analysis technique.

\section{Thematic Analysis}

The collected data is presented under the following themes.

\section{Importance of English Textbooks}

English textbooks are taken as a challenge as director manuscript admitted that cultural and national ideologies are shared and spread through textbook. He added:

"English is spread like an umbrella under which we find all information of not only science and technology but also sociocultural and economic conditions of a country. English textbooks are usually taken by evaluators and researchers for comparison and evaluation of syllabus, standard of education and educational system."

It shows that English Textbooks are compiled through a process and its importance demand various level of expertise. It is kept in mind that the content presented in Textbooks must matches the education system of the country and meets the educational requirements of the students. It also shows that English is considered very important in Pakistan and is given special attention. Writer-1 was also found aware of the importance of English by saying that "due to its emerging understanding about its importance at national and international level English has been made compulsory in primary level, contrary to the previous practices when it was started in secondary level". He very clearly asserted that it is the dire need of time that the English textbooks ought to be the best regarding text and visuals to further initiate and keep up the process of higher learning which is all in English language. 


\section{Understanding of Gender}

The researcher also tried to explore the gender awareness level among stakeholders who were officers responsible for English textbook publication of Punjab Textbook Board. Though they admitted that they have a firm faith in gender equitable representation but still gender stereotypes survived in the Textbooks is a bitter truth. This thing shows that the people behind the compilation of these textbooks still have gender biasness in their minds and stereotypes which consciously or un consciously penetrate and appear, if not apparently or obviously in verbal communication or text then at least in non-verbal text in a hidden way. On the question of how do you define gender they explained it in the same old way of two categories of male and female. Though they agreed to make it a part of syllabus and stated that it's already been made a part of syllabus. When this question was basked from director manuscript he said:

"Gender is presence of male and female whereas; gender

biasness is that if a story is written and some male are indicated

in it than if there is a space for knitting or home economics

related thing things than some girls should be shown so that both

of them would have the equal representation".

This shows typical understanding of male and females' role segregation which further perpetuate social complexities and deep-rooted gender role discrimination in the society. In answer to the query of gender stereotyping and the way it is treated or being portrayed in English textbooks the director manuscript very proudly asserted that now many things are different and will be reformed more in the future which will be reflected in English textbooks of Punjab too. When asked from the Writer-2 about the meaning of gender, he very confidently answered that it is the equal representation of both male and female. He further added, 'in illustrations even, gender equality is kept under consideration. If in any text, the hero is taken from religion or history then we try to represent a woman too'. He further added that this gender awareness is part of the curriculum development process. Publisher -1 said that according to SOP's in the style guide of Punjab Text Book Board we keep in consideration the representation of both girls and boys in the units and especially on cover pages of the books.

\section{Importance of Visuals Literacy}

Along with the verbal, non-verbal communication was equally emphasized by the authors and directors. Visuals were declared a helping hand for the teachers to explain themes for the junior level and as a self- 
explanatory part of information for the students. But they remained unable to express true meaning of visual literacy. Their belief in importance of images and visuals were more for the decoration purposes instead of being informational or didactic. Here comes the researcher's major emphasis in this article that the persons responsible for English textbooks publication were unable to explain the concept of visual literacy then how can they give equal importance to the concepts such as gender while illustrating in the visuals used in the textbooks. Almost all the participants expressed that images are used in the textbooks just for decoration and for the help of the teacher to explain the concept further but without any feeling of true gender concept. They were almost unaware of the literary aspect of visuals and its importance in education with using it in a way of teaching various concepts to the students successfully.

\section{Gender Illustration through Visuals}

Almost all the participants were found unable to explain that how appropriate gender roles or equitable gender representation can be illustrated through images. They expressed in a lay man's understanding that images in the textbooks help teacher in explaining the concept of different things and professions. How powerful an image can be in building a child's approach towards gender roles in the society or transforming various social structures causing oppression in the society, was the aspect of the query which was not clearly expressed by any of the persons interviewed. Importance was not given to the cover pages of textbooks. Publishers admitted that they remain least interested to make cover pages' student friendly. If a book looks attractive, student will enjoy reading it. They were questioned about the significance and the process of designing cover pages. Director manuscript said that it is tried to make cover page according to the age and grade of the students' attention. He said, 'cover page is a gate way to capture the student. The purpose of a book cover is to deliver the theme of the book in a distinct manner,' he added.

The illustration of gender roles and activities by showing men working in offices, women busy in household chores, girls helping their mothers in household tasks and boys playing outside home seemed quite a normal for government officials responsible for textbook writing. Writer-1 expressed that 'there is a separate team who decide about the visuals including cover page illustrations and style of the visuals'. He further made it clear that usually 2 or 3 visuals along with cover page illustrations are prescribed and any one of them is finalized to be printed. Writer 2 gave a very detailed answer saying, 
"Writer of a book doesn't write book, he writes manuscripts. Way to design a book is the process of getting an author's manuscript into the hands of a reader, by materializing it and giving it a form. An effective book cover desires to make a reader 'feel' it rather than 'tell' them something."

\section{Visual Clarity in Textbooks}

The officials showed their helplessness in reply to the question of pictorial representation along with their color, size, appearance, getup, and dressing and the types like images, sketches and illustrations. They admitted that most of the pictures in Punjab textbooks are unrecognizable and they defended it by arguing that pictures occupy space which is a limitation, The Director manuscript declared the position of Punjab curriculum and textbook board as a regulatory body, in defense. Publisher1 and 2 explained that they were not responsible for any loopholes in representation of roles of males and females as the finalized material for the publication come after fulfilling guidelines and SOPs at the end of open competition. In reply to the question that pictures and images should be the best representation of the text all agreed but, explained many reasons for not getting it. Director manuscript added that the concept is presented by author, polished by designer and approved by

the experts. He said, 'budget of the govt. is limited but the number of students and cost of books are increasing day by day. To counter this situation, we minimize the number of pages. Yes, we agree that due to this, student find boredom and fail to get the desired results and impact'.

With reference to the policy of taking and selecting the images and pictures the publisher 1 explained that usually visuals are not copied from the net but the images and pictures which are related to historical buildings, personalities or human and animal body parts, we take from net for they remain same and clearer. Publisher 2 added that sometimes writers also finalize the visuals for their text which we do not object and publish as it is.

\section{Constraints Identified}

Writer-1joinedPunjab Textbook Board as an assistant subject specialist with the degree of M.A education. Later on he did M.A and then M. Phil English and promoted as a senior writer with the experience of 15 years. He became emotional on the policy related matters and expressed with a sigh that, 'yes we all are responsible but in reality this system has made some people very helpless that their heart can bleed only and cannot implement whatever they feel good'.Publisher-1 
appreciated the current syllabus as more progressive and explanatory. In response to the visual literacy he said, 'Pictures should be to enhance the interest of the students but there are financial constraints. If we increase the quality of book it becomes costly and out of buying capacity. So we try to give maximum the best in minimum cost'. Director manuscript pointed towards the individual interference of the people in the process of preparing and publishing textbooks. He said, 'subjective approach should be replaced with the objective approach after having a situational analysis of the schools and syllabus'. Publisher 2 compared the publishers of other countries with the publishers of Pakistan and admitted that here publishers lack basic facilities and resources to come up with quality books. Writer1 revealed a secret that Punjab Textbook Board hire some writers who, instead of being a subject specialist, write books on different subjects. He further added that Punjab Textbook Board is a welfare organization which still needs to be developed. Writer 2 second the writer 1 and added that the writers of this board should have handsome remuneration for the better standard and to meet the desired requirements which are already mentioned in the style guide.

\section{Discussion}

Education through the textbooks is considered a key instrument to achieve equitable relationship among men and women but it itself is generating and strengthening disparities among males and females (Durrani,2008;Humphreys, 2005).But Punjab Textbook Board's officials are found less aware of this open secret. Even they seemed less sensitive to their practical solution. Purpose of education is to make people ready to embrace diversity and provide space to others rather than making it a process of close mindedness (Gulab,2018).State institutions are responsible for naturalizing the national identity but it is observed that gender identities like national identities achieve natural status through repetition or regulating a pattern of gender norms. So the national curriculum which is produced and controlled officially promotes and lubricates gendered identities with the acceptance of these identities as national identities. Gendered domestic and public space, work, and dress code, everyday characters and national icons are not only developed but sustained through these textbooks. Gender biasness must be stopped in text and visuals as the examination of the textbooks have proven that women are either discriminated or invisible in illustrations (Khurshid, Gillani \& Hashimi,2010). School is one of agent of socialization which work to perform national identities on individual and national level (Butler, 1990).

In dissemination of knowledge through verbal and non-verbal ways, not only the writers but directors and all members of textbook board are stakeholders and the present study found lack of capacity in the officials to understand and respond the very current issue of gender representation 
in the Textbooks' publication. Whatever is presented in textbooks reveal the thinking pattern of all these people and shows their point of view with reference to context of their values, culture and gender portrayal. Syllabus is designed and approved with their gender ideology which is reflected in verbal and non- verbal communication. Even though our society is striving for prosperity, the constant interference of stereotypical roles stops us from moving further up. The educational nagging is intended with a wider and panoramic outlook of accomplishing basic education for all, is not a utopian version. Reality is more than this. Just to make a book in access of all the students is lesser important than to keep an eye on the material presented in it. This study shows that material, social, political and religious factors are influencing the writers and publishers of the textbooks.

\section{Conclusion}

As ministry of education stands for eliminating any gender biasness from the curriculum (Ministry of Education, 2003), the persons responsible for curriculum development and publication are not gender sensitized. Male dominancy is clearly found in the textbooks (Skelton\& Ullah, 2013) and the responsible are not aware of this fact that there is representation of traditional gender roles in the visuals. The absence of academic and informative consideration to visuals and visual structures of meaning at such critical time, when images are initiated to dictate and govern the survives of the learners and students, are thoughtful challenges to teachers, writers, publishers and other stake holders (Serafini,2010).Our brains are reinforced to process pictures quicker than words. A great cover helps the reader promptly spot that this book is for them. But unfortunately the cover pages of Punjab Textbooks Board's books are not designed according to the grade. Some of the textbooks have such pictures which are of animals or strange object making no sense and students find no attraction or affiliation with them. To develop good quality curriculum and most relevant textbooks, it requires well trained and well equipped teachers (Qazi et al, 2010) but Punjab Textbook Board lacks such experts and involvement in curriculum development. Teachers and parents should try to explain and discuss the visuals in positive and constructive way to mitigate the effects of gender biasness. In order to sensitized the people involved in the process of book preparation, seminars, orientation and refresher courses should be conducted prior the course development. Gender sensitized courses and training sessions should be designed for the people involved in the publication of the textbooks. Without taking some serious steps, to explain the true sense of gender and to be optimistic about its implication in English textbooks through the current officials, is a hard nut to crack. 


\section{References}

Akbar. T, Malik. R, \& Azam. F. (2018). Gender Issues in Children's Literature: An Analysis of Fairytales. Pakistan Journal of Education, 35 (1)559-70

Briggs. S. (2015). Why visual literacy is more important than ever $\& 5$ ways to cultivate it. Retrieved from: https://www.opencolleges.edu.au/informed/features/why-visualliteracy-is-more-important-than-ever-10-ways-to-cultivate-it/

Butler, J. (1990). Gender Trouble. London and New York; Routledge

Chiponda, A., \& Wassermann, J.(2015). An analysis of the visual portrayal of women in junior secondary Malawian school history textbooks. Yesterday and Today, 14.

Durrani, N \& Halai, A \& Kadiwal, L \& Rajput, K \& Novelli, M \& Sayed, Y. (2017). Education and Social Cohesion in Pakistan. A Technical Report 10.13140/RG.2.2.13886.89922.

Elkins, J. (2010). The concept of visual literacy and its limitations, in: Visual Literacy. New York, New York: Rutledge. (217)

Fairclough, N., \& Wodak, R. (1999). Critical discourse analysis. In T.van Dijk (ED). Discourse as social interaction.258284.London: Sage

Gopang, A, S \& Shaikh, I, S; Parveen, D, S \& Khan, D, M. (2012).Critical Analysis of Textbooks of English(Compulsory) Class IX and, Published by Sindh Textbook Board, Jamshoro, Pakistan. International Journal of Research in Linguistics and Social Sciences

Gulab, F. \& Khokhar, A, J. (2018). Content Analysis of Language Textbooks (English, Urdu, Sindhi) for Inclusivity. Journal of Education \& Social Sciences, 6 (1) 55-70

Gulzar, S. (2017). An Evaluation of English Textbook at Matriculation level in Multan division, Pakistan. European Journal of English Language Teaching, 2 (4). ISSN: 2501-7136 
Halai, A. \& Durrani, N. (2018). The impact of education on social cohesion is multifaceted, with education being both a conflict driver and a means to mitigate it. International Journal of Educational Development, 61 (27-39).

Halliday, M,A K. (1997). An introduction to functional grammar( $2^{\text {nd }}$ Ed.).London: Edward Arnold.

Kaur, M. (2018).Gender differences in textbooks: An obstacle on the road to gender equality in society.Jour,5.

Khurshid, K., Gillani,I.G.\& Hashmi, M.A. (2010).A Study of the Representation of Female Image in the Textbooks of English and Urdu at Secondary School Level.Pakistan Journal of Social Sciences (PJSS). 30(2), 425-437

Kobia, J, M. (2009). Femininity and masculinity in English primary school textbooks in Kenya. The International Journal of Language Society and Culture, 28, 57-71

Kress, G. \& Leeuwen, T.V (2006). Reading Images: The grammar of visual design. London New York: Routledge.

Kasmaienezhadfard, S., Pourrajab, M., \& Rabbani,(2015).Effects of pictures in textbooks on student's creativity. Multi-Disciplinary Edu Global Quest (Quarterly),4(2).

Ministry of Education. (2009). Education in Pakistan. Retrieved from

http://www.pakteachers.org/uploads/files/publications/NationalEducation-Policy.pdf

Mirza, M. (2004). Gender analysis of school curriculum and textbooks. UNESCO: Islamabad.

Paechter, C. (2006). Reconceptualizing the gendered body: learning and constructing masculinities and femininities in school. Gender and Education, 18(2).

Pakistan Bureau of statistics, Government of Pakistan (2017). Provisional summary results of 6th population and housing census. 
Qazi, W., Rawat, k, J., Hamid, S., \& Simon, H, C. (2010). A free textbook distribution process in Sindh, Pakistan: A study of stakeholders' perceptions. Curriculum and Instruction Faculty and Staff Scholarship, 54

Rind, I. A. (2015). Gender identities and female students' learning experiences in studying English as Second Language at a Pakistani University. Curriculum \& teaching studies, cogent education 2: 1115574

Serafini,F.(2010).Reading Multimodal Texts: Perceptual, Structural and Ideological Perspectives. Children's Literature in Education 41:85-104 DOI 10.1007/s10583-010-9100-5

Skelton, C.,\& Ullah, H. (2013).Gender representation in the public sector school's textbooks of Pakistan. Educational Studies, 39 (2).

Sovic, A.,\& Hus, V. (2015). Gender stereotype analysis of the textbooks for young learners. Procedia - Social and Behavioral Sciences, 186. $495-501$.

Tajeddin, Z.,\& Enayat, M.J. (2010). Gender representation and stereotyping in EL

textbooks: A critical image analysis. TELL, 4(2), 51-79.

Truce, B., Blanc, M.,\& Cambre, C. (2018). Visibilities and visual discourses: Rethinking the social with the image. SageDOI: $10.1177 / 1077800418792946$.

Ullah,H.,\& Skelton, C. (2013). Gender representation in the public sector school's textbooks of Pakistan, Educational Studies, 39:2, 183-194

UNESCO. (2004).Literary trends in Pakistan. Ialamabad: UNESCO.

UNESCO. (2015a). Education for All 2000-2015: Achievements and Challenges (EFA Global Monitoring Report 2015). Paris: UNESCO.

UNESCO. (2015b). Gender and EFA 2000-2015: Achievements and challenges. Gender Summary. Paris: UNESCO. 
Woodak, R. (1999). Gender and discourse. Contemporary Sociology.28(4).

Yazdanmehr, E., \& Shoghi, (2014). Design and application of a 'Textbook visual effects' evaluation checklist. Theory and Practice in Language Studies, 4 (3), 473-480.

\section{Citation of this Article:}

Akbar, T., \& Malik, R. (2020). Semiotic analysis of English books of Punjab textbook board (Pakistan) with gender lens: Exploring the gender sensitization level of Punjab textbook board officers. Pakistan Journal of Education, 37 (1), 113-128. 